\title{
Tax Information Exchange Agreements and the Prohibition of Retroactivity
}

\author{
Anna B. Scapa Passalacqua, ${ }^{\text {b }}$ Addy Mazz, ${ }^{c}$ Pasquale Pistone, ${ }^{d}$ Natalia Quiñones, ${ }^{e}$ Jennifer Roeleveld, ${ }^{\mathrm{f}}$ Luís Eduardo
} Schoueri $^{\text {g }}$ \& Frederik Zimmer ${ }^{\text {h }}$

This article presents a study of the retroactive application of tax information exchange agreements (TIEAs) in Brazil, Colombia, South Africa and Uruguay, with a view to articulating policy recommendations for similar emerging economies.

Contracting states should adopt clear rules in their TIEAs as regards their temporal application. In the absence of such rules, contracting states should abstain from applying a TIEA retroactively. The authors further recommend that legislatures adopt clear rules in domestic law governing whether a TIEA should apply to pending proceedings at the time of signature of the TIEA.

Countries wishing to provide for retroactive effect in respect of information that is still open for review under statute of limitations rules may include provisions to reflect this both in domestic law and in the TIEA itself. It is recommended that countries carefully review and agree whether exchanges of information should be restricted for cases that already have been subject to a reassessment proceeding and, thus, are closed, even when the statute of limitations period has not lapsed.

Legislatures in emerging countries should also take a position in domestic law on the issue of whether taxpayer rights may be limited as the result of a retroactive TIEA application.

\section{INTRODUCTION}

Globalization has significantly increased cross-border commercial and financial activity, converting the private sector into largely a world without borders. This has clearly positive effects for the global economy, but it has also increased opportunities for moving capital abroad and international tax avoidance and evasion.

International cooperation in tax matters through exchange of information is essential for tax authorities dealing with the challenges arising from globalization and to achieve tax transparency. Such cross-border cooperation can be facilitated by different legal instruments. These instruments can include, in particular, bilateral or multilateral comprehensive tax treaties that contain a specific provision dealing with exchange of information, as well as more specific agreements providing for the exchange of tax information, such as a tax information exchange agreements (TIEAs). ${ }^{1}$

\section{Notes}

a This article condenses and articulates the findings set forth by several academic institutions involved in the DeSTaT Research Project (Sustainable Tax Governance in Developing Countries through Global Tax Transparency) as 'South Antennae' on the basis of Questionnaires drafted by the 'North Research Units' of the same Project. The South Antennae are composed of four research units representing Brazil, Colombia, South Africa and Uruguay. Funding for the Project is provided by the Research Council of Norway. Further information about the Project can be retrieved from the UiO Department of Public and International Law, Sustainable Tax Governance in Developing Countries Through Global Tax Transparency - DeSTaT, http://www.jus.uio.no/ior/english/research/projects/global-tax-tranparency/ (accessed 31 Jan. 2018).

bY Norway. She can be contacted at anna.berna.passalacqua@no.ey.com. The views expressed in this article do not necessarily reflect the views of EY Norway Professor of Public Finance Law, Universidad de la República, Montevideo, Uruguay. Email address: addymazz@hotmail.com.

A Academic Chairman, International Bureau of Fiscal Documentation; Jean Monnet ad Personam Chair of European Tax Law and Policy, Institute for Austrian and International Tax Law (WU, Vienna, Austria); Professor of Tax Law, University of Salerno, Italy. Email address: pasquale.pistone@wu.ac.at.

Researcher, Colombian Tax Institute, professor of International Taxation at Universidad de los Andes and Universidad del Rosario. Email address: nquinones@quinonescruz. com.

f Professor of Tax, University of Cape Town, Cape Town, South Africa. Email address: Jennifer.Roeleveld@uct.ac.za.

g Professor of Tax Law, Universidade de São Paulo, São Paulo, Brazil. Email address: schoueri@lacazmartins.com.br.

h Professor Emeritus of Tax Law, University of Oslo, Norway. Email address: frederik.zimmer@jus.uio.no. Special acknowledgment to L.A. Henie, LL.M. International Taxation (Leiden), C. West, Associate Professor of Tax (University of Cape Town) and to Professor I.J.J. Burgers (University of Groningen) for providing their comments to this article. With regard to the specific topics addressed in this article, the following persons acted as reporters for the respective research units: Brazil: C.O. Ferreira de Almeida and M.C. Barbosa; Colombia: N. Quiñones; South Africa: C.D. de Villiers, A. Marais and J.J. Roeleveld; and Uruguay: A. Blanco.

A TIEA can also serve as an instrument to implement, in practice, the multilateral convention on mutual assistance. For a review of the pros and cons that the conclusion of a comprehensive tax treaty including an exchange of tax information clause presents for developing countries compared to the conclusion of agreements 
Provisions regarding exchange of tax information establish, in part, the framework for such international cooperation and set forth the rights and obligations applicable to tax authorities requesting tax information about income that 'their' taxpayers derive in other countries. The right to request information, in the absence of a provision to the contrary, generally applies with regard to taxes from the date of entry into force of the agreement. However, it is not clear whether tax authorities may apply such exchange of information provisions with retroactive effect so as to request information relevant for the assessment of taxes that arose before the date of entry into force of the particular agreement.

There are two research questions addressed in this article. The first concerns whether retroactive TIEA application should be allowed for developing countries and, if so, under what circumstances. The second question concerns whether such retroactive application would be acceptable considering (1) the principle of non-retroactivity under the Vienna Convention on the Law of Treaties (Vienna Convention), (2) the positions of the OECD and the United Nations concerning temporal application of TIEAs and comprehensive tax treaties and (3) the principles of transparency and good tax governance.

This article will assess these research questions in the context of the TIEAs entered into by Brazil, Colombia, South Africa and Uruguay (the surveyed countries). This article will also review the case law of the surveyed countries concerning the application of exchange of information provisions in comprehensive tax treaties (tax information exchange provisions). As both TIEAs and tax information exchange provisions are intended to provide for mutual assistance to the contracting states, it is considered that such case law provides relevant guidance for interpreting the provisions of a TIEA.

To address the research questions, the article is structured as follows:

The second section of this article introduces the principle of non-retroactivity established in the Vienna Convention and assesses when the provisions of a TIEA may be considered as having retroactive effects. This section examines also whether a TIEA provision may be considered as a procedural rule and, thus, whether a TIEA provision can have an impact on actions and events that occurred before the TIEA has effect in the respective contracting state.

The third section assesses whether the OECD and/or the UN support or reject the retroactive application of a TIEA. The provisions addressing the temporal scope of application of a treaty in the OECD Model Agreement on Exchange of Information in Tax Matters (OECD Model TIEA), ${ }^{2}$ in Article 26 of the OECD Model Tax Convention on Income and on Capital (OECD Model Tax Convention) ${ }^{3}$ and in Article 26 of the UN Model Double Taxation Convention between Developed and Developing Countries (UN Model Tax Convention) ${ }^{4}$ will provide the primary evidence for the assessment.

The fourth section tests whether the TIEAs entered into by the surveyed countries may have retroactive effects by allowing exchange of information concerning actions or events that occurred before a TIEA enters into force. This section considers the relevant provisions of the TIEAs signed as at 11 November 2017, the relevant legal policy considerations and the practice and case law in each of the surveyed countries.

The fifth section considers whether a TIEA, with retroactive effect, is in accordance with the principles of good tax governance and fiscal transparency. These principles form the core research question of the overall DeSTaT project aimed at developing sustainable tax governance in developing countries through global fiscal transparency. ${ }^{5}$ For the purposes of this article, it is submitted that global fiscal transparency supplements the establishment of good tax governance ${ }^{6}$ insofar as it allows each country to effectively exercise its taxing rights on cross-border transactions.

Finally, the sixth section will provide selected tax policy recommendations for the exchange of information concerning actions or events that occur before a TIEA enters into force.

This article does not provide an exhaustive analysis of all limitations imposed by the OECD Model TIEA or

\section{Notes}

concerning only the international exchange of tax information, see T. Dubut et al., General Tax Treaties vs. T.I.E.A.s: Assessing Tools to Ensure Transparency in a Globalised World from the Perspective of Developing Countries (19 Jan. 2016), http://www.jus.uio.no/ior/english/research/projects/global-tax-tranparency/publications/ general-tax-treaties-vs-t-i-e-a-s-assessing-tool-html (accessed 31 Jan. 2018).

OECD, Model Agreement on Exchange of Information in Tax Matters (OECD 2002).

OECD, Model Tax Convention on Income and Capital (OECD 2017).

4 United Nations, Department of Economic and Social Affairs, United Nations Model Double Taxation Convention Between Developed and Developing Countries (United Nations 2011).

5 In the framework of the DeSTaT project, the approach of this article combines good governance and fiscal transparency based on the argument that global fiscal transparency supplements the establishment of good tax governance, insofar as it allows each country to effectively exercise its sovereignty on cross-border situations falling within the boundaries of its jurisdiction. UiO Department of Public and International Law and International Law, Sustainable Tax Governance in Developing Countries Through Global Tax Transparency - DeSTaT, http://www.jus.uio.no/ior/english/research/projects/global-tax-tranparency/ (accessed 31 Jan. 2018).

6 The principles of good governance have been addressed by the ECOFIN Council, which defined 'good governance in the tax area as meaning the principles of transparency, exchange of information and fair tax competition'. ECOFIN, Council Meeting 8850/08, Presse 113, 22 (14 May 2008). 
domestic law in relation to the exchange of tax information. Equally, the article does not address retroactive situations that may derive from a TIEA that establishes a date of entry into force that predates the date on which the TIEA becomes law in a specific country (under domestic law).

There is currently limited literature concerning the temporal effects of a TIEA and the research question under analysis. The principles against which such temporal effects have been tested in this article have been derived mainly from the Vienna Convention, which is generally recognized as customary international law, ${ }^{7}$ and from the OECD Model TIEA, the OECD Model Tax Convention and the UN Model Tax Convention. It is considered that, even though these models are not binding, they have substantial weight for interpreting tax treaties, especially when the tax treaty under review follows the wording of these models. ${ }^{8}$ These principles have been considered valid for the interpretation of the TIEAs entered into by the surveyed countries, as well as their case law and administrative practice regarding retroactivity.

\section{When Will a tieA have retroactive EFFECTS UNDER THE VIENNA CONVENTION?}

\section{I The Concept of Retroactivity}

Before any TIEA retroactive effects can be analysed, it is necessary to clarify the meaning of the term 'retroactivity' and distinguish it from the term 'retrospectivity'. While these terms are often used interchangeably, such use does not reflect the critical conceptual distinction that exists between them.

The difference between these terms was discussed at the 2010 annual meeting of the European Association of Tax Law Professors (EATLP) held in Leuven, Belgium. In the general report for that meeting, both terms are defined as follows:

the term 'retroactive' [will be used] for the situation in which a legal provision changes the past legal consequences of facts that occurred before the provision was officially published. In other words, the term is used where the legal provision is applicable to taxable events that occurred prior to its official publication. The term 'retrospective' will be used for the situation in which a new legal provision has 'immediate effect', without grandfathering existing situations, and as such is also applicable to the future consequences of transactions or events that have already happened. ${ }^{?}$

Accepting this distinction, in the context of this article, exchange of information authorized under a TIEA with respect to information for the determination, assessment or collection of taxes that have arisen prior to the date on which the TIEA enters into effect is considered 'retroactive'. The critical determinant is whether the action or event (e.g. income earned, expenses incurred, transaction executed) to which the tax law attaches consequences (a taxable action or event) occurred prior to entry into force of the TIEA.

As established by Sasseville in relation to the temporal application of Article 26 of the OECD Model Tax Convention, the treaty provisions regarding exchange of information:

will have effect as regards information necessary for carrying treaty or domestic law provisions relating to the taxes levied after the date specified in these coming into effect provisions. In other words, while there does not appear to be any restriction to the application of article 26 based on when the information itself originated, there is, in many treaties, a restriction based on when the taxes for which the information is necessary are levied. ${ }^{10}$

Many comprehensive tax treaties and TIEAs have retrospective effects. These effects arise as described by Sasseville, namely that the information exchanged may relate to actions or events prior to the entry into force of the treaty or TIEA, but such actions or events pertain to the determination of tax liabilities after the entry into force. Retroactive effect, in contrast, permits the information exchange with respect to actions or events prior to the entry into force of the treaty or TIEA, but which also pertain to tax liabilities arising prior to the entry into force of the treaty or TIEA. It is this latter circumstance that is the subject of this article.

\section{Notes}

I. M. Sinclair, The Vienna Convention on the Law of Treaties 85 (2d ed., Manchester University Press 1984). See also O. Corten \& P. Klein, The Vienna Conventions on the Law of Treaties: A Commentary vol. 1, 719-720 (18th ed., Oxford University Press 2011).

8 Both of the Commentaries on the UN and OECD Model Tax Conventions provide comments regarding their role in treaty interpretation. Para. 12 of the introduction to the UN Model Tax Convention states that '[i]ts provisions are not binding and should not be construed as formal recommendations of the United Nations. Rather, the United Nations Model Convention is intended to facilitate the negotiation, interpretation and practical application of bilateral tax treaties based upon its provisions'. Similarly, para. 29 of the introduction to the OECD Model Tax Convention indicates that the Commentary can 'be of great assistance in the application and interpretation of the conventions and, in particular, in the settlement of any disputes'.

H. Gribnau \& M. R. T. Pauwels, General Report, in Retroactivity of Tax Legislation, EATLP International Tax Series, No. 9, 43 (H. Gribnau \& M. R. T. Pauwels eds, EATLP/ IBFD 2013).

10 J. Sasseville, Temporal Aspects of Tax Treaties, in Tax Polymath: A Life in International Taxation - Essays in Honour of John F. Avery Jones, 61 (P. Baker \& C. Bobbett eds, IBFD 2010). 
The distinction above is illustrated by a circular issued by the Luxembourg tax authorities on 31 December 2013 regarding the application of the principle of non-retroactivity to exchange of information on request. According to this circular, 'the principle of non-retroactivity does not stand against the passing on of data from year(s) prior to the coming into force of the Convention, as long as the data to be passed on is likely relevant to determine taxable income in respect of the tax year covered by the Convention'.

\subsection{The Principle of Non-Retroactivity}

Article 28 of the Vienna Convention, which recognizes the principle of non-retroactivity, provides as follows:

Unless a different intention appears from the treaty or is otherwise established, its provisions do not bind a party in relation to any act or fact which took place or any situation which ceased to exist before the date of the entry into force of the treaty with respect to that party.

It is clear that this provision does not establish an absolute prohibition against the retroactive application of tax treaty provisions. However, there is a general presumption against retroactivity unless the contracting states agree on a retroactive application of the provisions included in the treaty. In the context of tax treaties, Sasseville confirms that if the contracting states wish to give retroactive application to a treaty provision, they can do so subject to having to establish that this was their intention', ${ }^{11}$ reiterating the principle from Article 28 of the Vienna Convention.

It is submitted that a TIEA would have to have a clear provision, or evidence of similar standing, permitting retroactive application - otherwise Article 28 of the Vienna Convention would operate to deny the retroactivity. ${ }^{12}$

\subsection{Retroactive Application of Procedural Rules to Pending Proceedings}

While the denial of retroactive application of a treaty in the absence of an authorizing provision may be clear with respect to substantive law, the same may not be true of procedural law. The temporal effect of a law may depend on the character of the rule concerned.

Substantive law can be defined as the part of the law that creates, defines and regulates the rights, duties and powers of the parties'. ${ }^{13}$ By contrast, procedural law is the 'machinery' for enforcing those rights and duties. Procedural law comprises the rules by which a court hears and determines what happens in civil or criminal proceedings, as well as the method and means by which substantive law is made and administered. ${ }^{14}$ While not all countries distinguish between the application of substantive law and procedural law, ${ }^{15}$ the fact that some do may create a conflict with regard to the rights and obligations in applying a TIEA.

The relevance of the distinction between substantive and procedural rules for determining the temporal application of a law has been recognized by the European Court of Justice (ECJ), establishing, at least for the EU, that a substantive rule may be applied only to taxable events occurring after the date on which the rule enters into force. In contrast, a procedural rule is directly applicable to pending proceedings. ${ }^{16}$

In the context of TIEAs, the issue of pending proceedings deserves specific attention, as a prior taxable action or event could be subject to a pending proceeding at the time the TIEA enters into effect. This is relevant for TIEAs that do not provide clear guidelines regarding whether a TIEA may be applied retroactively to such previous taxable actions or events.

There is no general definition of the term 'pending proceedings'. In principle, a pending proceeding may exist where there is a pending tax assessment concerning a taxable action or event that occurred before the TIEA enters into effect. Under a broad interpretation, a pending proceeding may also refer to situations where the tax authorities are entitled to start (or open again) $)^{17}$ a tax assessment proceeding in accordance with the time limits imposed by the domestic statute of limitations. Such interpretation could imply

\section{Notes}

11 Ibid., at 58 .

12 Art. 28 of the Vienna Convention is generally recognized as customary international law, Sinclair, supra n. 7. This requires that a TIEA be interpreted in accordance with the principle of non-retroactivity included in Art. 28 and that a failure to comply with it will be resolved based on the rules established in the TIEA itself e.g. through the rules governing the mutual agreement procedure (see Art. 13 of the OECD Model TIEA).

13 B. A. Garner, Black's Law Dictionary 1443 (7th ed., West Group 1999).

14 Ibid.

15 In the General Report by Gribnau \& Pauwel, supra n. 9, at 51, the following countries were identified as distinguishing between substantive and procedural rules for determining the application of a tax law to previous taxable events: Belgium, France, Germany, Greece, Hungary, Italy, Luxembourg, the Netherlands, Poland, Portugal, Sweden, Turkey and the United Kingdom. Colombia also distinguishes between substantive and procedural rules and generally allows the application of procedural rules to previous taxable events.

16 In De Haan, Case C-61/98, EU:C:1999:393 (7 Sept. 1999), para. 13, the ECJ ruled that 'procedural rules are generally held to apply to all proceedings pending at the time when they enter into force, whereas substantive rules are usually interpreted as not applying to situations existing before their entry into force'. That guidance is also followed in the judgment of the ECJ in Commission v. Moravia Gas Storage, Case C-596/13 P, EU:C:2015:203 (26 Mar. 2015), para. 33.

17 The possibility to reopen a tax audit procedure will depend on domestic law, but - in principle - it should be considered acceptable only in exceptional circumstances. This issue is reviewed further in s. 6.2 . 
that exchange of information requests may be permitted in relation to taxable actions or events that occurred before the TIEA enters into effect, provided that the statute of limitations rules have not expired.

The above examples demonstrate that the definition of pending proceedings can have an impact on whether information related to actions or events that occurred before a TIEA has effect may be exchanged between the contracting states. There is thus a need to assess whether the rules under a TIEA are to be regarded as procedural rules, substantive rules or both procedural and substantive rules.

It can be argued that TIEAs are procedural rules, ${ }^{18}$ as they do not give rise to a new tax obligation, but they provide tools to the tax authorities of the contracting states to obtain information that can be relevant for the assessment of taxes under domestic law. ${ }^{19}$ This view is criticized by Sansonetti, ${ }^{20}$ who argues that, from a theoretical perspective, the administrative tax assistance provisions (including tax information exchange provisions) are of a not only procedural, but also substantive nature. $\mathrm{He}$ argues that:

the immediate application of a new procedural law to an ongoing procedure is based on the idea that the procedural rules are so to speak value-neutral and that, consequently, they do not affect the person or the so-called principle of legitimate expectations. In this sense, new procedural rules appear as useful and convenient, without triggering a change of the legal order. The provisions related to administrative assistance are, however, not of a pure procedural nature since they have at least an indirect impact on the legal position of the individuals affected ... In addition, the distinction between procedural law and substantive law is not always straightforward. ${ }^{21}$

The position of Sansonetti can be challenged by the fact that most procedural rules are not of a 'purely' procedural nature, as such rules directly or indirectly affect the legal position of the persons affected.

The review shows that a TIEA contains provisions of heterogeneous character and, thus, some of its provisions can be considered substantive and others procedural rules. For example the rule under a TIEA establishing its object and scope can be considered substantive, as it defines the rights and obligations of the parties and the type of information that may be requested through a TIEA. By contrast, the rules of a TIEA regulating the exchange of information process can be considered procedural, as they govern the manner in which information is to be exchanged. The application of the procedural rules may require the application of the substantive provisions in order for the TIEA to have effects.

Based on the above, the authors submit that the distinction between substantive and procedural rules is not suitable for determining the temporal application of a TIEA to a pending procedure. Rather, the temporal application should follow the entry into effect provisions established in the TIEA itself and Article 28 of the Vienna Convention.

\section{OECD AND UN POSITION IN RELATION TO THE TEMPORAL APPLICATION OF A TIEA}

\section{I OECD Model TIEA}

The temporal application of a TIEA ${ }^{22}$ is governed by Article 15(3) and (4) of the OECD Model TIEA, which provides as follows:

3. This Agreement shall enter into force on 1 January 2004 with respect to exchange of information for criminal tax matters. The Agreement shall enter into force on 1 January 2006 with respect to all other matters covered in Article 1.

4. Unless an earlier date is agreed by the Contracting Parties, the provisions of this Agreement shall have effect:

- with respect to criminal tax matters for taxable periods beginning on or after 1 January 2004 or, where there is no taxable period, for all charges to tax arising on or after 1 January 2004;

- with respect to all other matters described in Article 1 for all taxable periods beginning on or after January 12006 or, where there is no taxable period, for all charges to tax arising on or after 1 January 2006.

\section{Notes}

18 This position has been taken by the South African Courts in the cases described in s. 4.3 .3 below.

19 S. A. Rocha, Exchange of Tax-Related Information and the Protection of Taxpayer Rights: General Comments and the Brazilian Perspective, 70(9) Bull. Int'l Tax'n 515 (2016).

20 P. Sansonetti, Retroactivity in the Exchange of Information on Demand, 83 ASA 11-12, 929 (2014/2015).

21 Ibid.

22 The OECD Model TIEA is presented as both a multilateral instrument and a model for bilateral treaties. The text and references to articles correspond to the multilateral version. 
Article 15 contains two different temporal rules, namely the entry-into-force rules and the have-effect rules. The entry-into-force rules establish when a treaty becomes binding between the contracting states, determining the date from which one contracting state may submit requests for information to the other contracting state. By contrast, the have-effect rules establish the information that may be covered by an exchange of information request. Unless the contracting parties have agreed an earlier date, the OECD Model TIEA provides that the requested information needs to be relevant for taxable periods or charges to tax arising on or after the date on which the TIEA has effect.

The above is supported by the Commentary on Article 15 of the OECD Model TIEA, which states that 'the rules of paragraph 4 [of article 15] do not preclude an applicant Party from requesting information that precedes the effective date of the Agreement [TIEA] provided it relates to a taxable period or a chargeable event following the effective date'. ${ }^{23}$ The have-effect rules are decisive as to whether a TIEA allows for a retroactive application of its exchange of information provision.

Article 15 of the OECD Model TIEA further establishes different dates of 'entry into force' and 'have effect' for requests concerning criminal tax matters and other tax matters, which would apply only if the contracting states have not agreed on an earlier date. For criminal tax matters, Article 15 states that the provisions of the agreement will enter into force and have effect from 1 January 2004. For other tax matters, this article states that the agreement will enter into force and have effect from 1 January 2006.

It is therefore necessary to consider how to interpret Article 15, especially in relation to the specific dates included in the OECD Model TIEA. The OECD Manual and Commentary do not provide guidance on these aspects.

One view is to follow a strict interpretation of the wording of Article 15, considering that the OECD recommends countries to use these dates (i.e. 2004 for criminal tax matters or 2006 for other tax matters) in their TIEAs, unless they agree on an earlier date. This would mean that these dates may be used also for TIEAs signed many years later, implying that the OECD advises an increasing degree of retroactivity over time.

Another view is that the OECD merely included these dates in the OECD Model TIEA as examples and thus that the contracting states are free to agree on the dates a TIEA will have effect, including a date before or after the TIEA is signed. State practice with respect to these dates can provide an indication as to the interpretation of the inclusion of specific dates in the Model TIEA.

A review of the TIEAs entered into by Brazil, Colombia, South Africa and Uruguay indicates that only one TIEA (that between South Africa and the Bahamas) adopts the date included in the OECD Model TIEA in relation to exchange of information concerning criminal tax matters (i.e. 1 January 2004), despite entering into force on 25 May 2012. The remaining South African TIEAs establish dates that differ from the OECD Model TIEA. A detailed analysis of the temporal provisions of the TIEAs entered into by Brazil, Colombia, South Africa and Uruguay is included below. From this review, one can conclude that the TIEAs signed by the surveyed countries (with only one exception) support the second view described above.

Furthermore, at the time the OECD Model TIEA was adopted (in 2002), the application of the TIEA provisions to information requests from 2004 and 2006 did not imply a retroactive application of the TIEA provisions. There is no indication in the OECD Model TIEA, Manual or Commentary that may suggest any intention by the OECD to recommend a retroactive application of the TIEA provisions for the TIEAs to be concluded in later years. Based on the above, this article concludes that the dates included in the OECD Model TIEA are set only as examples and that the OECD does not recommend a retroactive application of TIEAs allowing for information exchange from 2004 or 2006 onwards.

\subsection{OECD and UN Model Tax Conventions}

The OECD and the UN Model Tax Conventions also contain provisions regarding exchange of information, namely Article 26 in both Model Tax Conventions. These provisions are included in almost all tax treaties entered into by OECD and non-OECD countries, and share the same function of mutual assistance as that of TIEAs. This discussion here reviews the temporal rules applicable to exchange of information requests under a tax treaty in order to compare them against the temporal rules applicable to TIEAs.

The entry-into-force and have-effect rules of the OECD Model Convention are included in Article 30(2), which provides as follows:

\section{Notes}

23 See para. 114 Commentary on Art. 15(4) of the OECD Model TIEA. 
The Convention shall enter into force upon the exchange of instruments of ratification and its provisions shall have effect:

a) (in State A) ...

b) (in State B) ...

A similar provision is included in Article 29(2) of the UN Model Convention.

Both the OECD Model Convention and the UN Model Convention leave it open for the contracting states to decide when a tax treaty will have effect. While illustrative dates have not been inserted into these models, the lack of illustrative dates should not be considered a material difference between the OECD Model TIEA and the OECD and UN Model Conventions.

In addition, paragraph 10.3 of the Commentary on Article 26 of the OECD Model Tax Convention ${ }^{24}$ and paragraph 5.5 of the Commentary on Article 26 of the UN Model state as follows:

Nothing in the Convention prevents the application of the provisions of the Article to the exchange of information that existed prior to the entry into force of the Convention, as long as the assistance with respect to this information is provided after the Convention has entered into force and the provisions of the Article have become effective. Contracting States may find it useful, however, to clarify the extent to which the provisions of the Article are applicable to such information, in particular when the provisions of that convention will have effect with respect to taxes arising or levied from a certain time.

The wording of the quoted paragraph from the OECD Commentary indicates that a retroactive application of the exchange of information provisions of a tax treaty is not prohibited, even if such information pertains to tax periods or tax charges before the have-effect date of the treaty. Similarly to the OECD Model TIEA, the Commentary on the Model Tax Conventions contain a recommendation that the contracting states clarify such application in their tax treaties (as regards when the exchange of information provision will have effect and in relation to which taxes it will apply).

Unless the contracting states agree on a retroactive application of the treaty provisions (as permitted by Article 28 Vienna Convention), the entry into force article should restrict the temporal scope of application of the exchange of information provisions to information that is relevant for taxable periods or charges to tax after the have-effect date of the treaty. The fact that the information existed prior to the date of entry into effect of a tax treaty should not be decisive (see section 2.1).

The analysis above shows that both the OECD and the UN Model Conventions provide the same temporal rules for determining the information that may be exchanged on request by the other contracting state. ${ }^{25}$ The similar temporal provisions included in both the UN and the OECD Model Conventions may indicate that the position of developing countries and that of developed countries are similar in relation to retroactivity. Both Model Tax Conventions do not prohibit retroactivity, and recommend that contracting states agree on the dates from which the exchange of information provisions will have effect.

\section{TIEAs ENTERED INTO BY BRAZIL, Colombia, South Africa and URUGUAY}

Developing from the theoretical underpinnings above, this section reviews the temporal rules included in the TIEAs entered into by Brazil, Colombia, South Africa and Uruguay $^{26}$ and also analyses whether they have retroactive effects by allowing exchange of information concerning taxable actions or events that occurred before the TIEA enters into force.

The have-effect rules included in each of the TIEAs signed by the surveyed countries are classified into one of the following groups:

- Group A: TIEAs allowing for retroactive application for both criminal and non-criminal tax matters;

- Group B: TIEAs not allowing for retroactive application for criminal or non-criminal tax matters;

- Group C: TIEAs allowing for retroactive application only for criminal tax matters; and

- Group D: TIEAs potentially allowing for retroactive application only for criminal tax matters.

\section{Notes}

24 Hong Kong (China) has included its position on this paragraph of the Commentary, clarifying that 'in view of its domestic law requirements, Hong Kong, China will only exchange information relating to taxable periods after the agreement came into operation'.

25 Even though there are no substantial differences between Art. 26 of the OECD Model Tax Convention and Art. 26 of the UN Model Tax Convention in relation to the temporal scope of application of a treaty, there are certain differences in relation to other issues between these model conventions. For further information in that respect, see P. Pistone \& P. Schoueri, Exchange of Information and Mutual Assistance in the Collection of Taxes, in The UN Model Convention and Its Relevance for the Global Tax Treaty Network, WU Series vol. 7, 321-336 (M. Lang et al. eds, IBFD 2017).

26 The review of TIEAs entered into by each country is based on the information available on the IBFD, Tax Treaty Database, reviewed on 11 Nov. 2017. 
Graph 1: Groups of TIEAs that may have retroactive effects

\begin{tabular}{|c|c|c|}
\hline & RETROACTIVE & NON-RETROACTIVE \\
\hline Group A & All & \\
\hline Group B & & All \\
\hline Group C & Criminal & Non-criminal \\
\hline Group D & Criminal - unclear & Non-criminal \\
\hline & & \\
\hline
\end{tabular}

Graphic 1 illustrates the temporal differences between Groups A to D:

The red arrows in graphic 1 show which of the TIEA groups may allow for retroactive effects (i.e. Groups A, C and D) and whether such retroactive effects may apply in relation to any type of exchange of information. For example the graphic shows that the TIEAs included in Group A may allow retroactive effects in relation to any type of exchange of information, whereas the TIEAs included in Groups C and D may allow retroactive effects only in relation to requests covering criminal matters. This will be discussed in more detail below.

\section{I Brazil}

\section{I.I Classification of TIEAs Entered into by Brazil}

As at 11 November 2017, Brazil had signed TIEAs with ten countries, namely Bermuda, Cayman Islands, Guernsey, Jamaica, Jersey, San Marino, Switzerland, the United Kingdom, the United States and Uruguay, but only the TIEA with the United States had entered into force (in 2013). Brazil was also negotiating TIEAs with Andorra and Panama.

A review of Brazilian TIEAs indicates that Brazil includes similar rules for determining the dates of entry into force in all of its TIEAs. These rules provide that the date of entry into force would be the date of the later notification of the contracting parties of the completion of the domestic procedures required for bringing the TIEA into force.

By contrast, there is no common approach in relation to the have-effect rules. Using the classifications introduced at the start of section 4 , the have-effect rules can be classified as follows:

Group A: Brazilian TIEAs with the United States and with the United Kingdom have effect for requests made on or after the date of entry into force of the TIEA, without regard to the taxable period to which the requested information relates. Such classification appears to facilitate retroactive application for all information.

Group B: Brazilian TIEAs with the Cayman Islands and Switzerland provide that their exchange of information provisions will have effect from the date on which the TIEA enters into force, but only in respect of information concerning taxable periods beginning on or after that date or, where there is no taxable period, for all charges to tax arising on or after that date. There is no distinction between requests concerning criminal tax matters or other tax matters. These TIEAs would appear to facilitate only the prospective exchange of information

Group C: Brazilian TIEAs with Bermuda and with Jamaica permit a request for information regarding non-criminal matters only with respect to taxable periods beginning on or after the entry into force of the treaty or, where there is no taxable period, for all charges to tax arising on or after that date. However, for criminal tax matters, these TIEAs permit the exchange of information that existed at the time of the entry into force of the TIEA, without regard to the taxable period to which the criminal tax matter relates.

Group D: Brazilian TIEAs with Guernsey, Jersey, San Marino and Uruguay allow a request for information regarding non-criminal matters only with respect to taxable periods beginning on or after the entry into force of the treaty or, where there is no taxable period, for all charges to tax arising on or after that date. However, these TIEAs are unclear with respect to exchange of information concerning criminal tax matters. The TIEAs provide that they will have effect on their date of entry into force, without mentioning whether the other state may request information concerning a taxable period prior to the entry into force of the TIEA. This can be interpreted as allowing exchange 
of information existing at the time of entry into force (regardless of the taxable period), but this interpretation may be debateable.

The classifications above indicate that some Brazilian TIEAs allow exchange of information concerning taxable periods prior to the entry into force of the TIEAs and, thus, may have retroactive effects. This is especially the case for the TIEAs in Groups A and C and, potentially, for the TIEAs in Group D. The retroactive effects of the TIEAs in Group C and D refer only to requests for information regarding criminal tax matters.

\section{I.2 Legal Policy Considerations}

The Brazilian Constitution expressly prohibits retroactivity in Article 150, which provides as follows:

Notwithstanding other guarantees provided to the taxpayer, it is forbidden for the Union, the States, the Federal District and Municipalities:

\section{To charge taxes:}

a) In relation to events that have occurred before the effective date of the law which instituted or increases taxes;

This provision refers to substantive rules (determining, for example, the tax burden) and not to procedural rules. There is no clear position in Brazil regarding whether a TIEA or its provisions may be considered of a procedural or substantive nature, and thus whether the Brazilian Constitution would prohibit retroactive TIEAs.

Taxpayers' fundamental rights recognized in the Brazilian Constitution (such as due administrative process, the right to be informed and to appeal, the right to provide evidence, the inviolability of the data secrecy and the principle of legal certainty $)^{27}$ may serve to protect the right of taxpayers against retroactive TIEAs. Retroactive exchange of information could negatively impact a taxpayer by imposing retroactively a duty to retain records and evidence with respect to transactions before the TIEA entered into force.
Documentation that the taxpayer would otherwise have kept in the knowledge that information could be exchanged might have otherwise been disposed of, restricting the ability of the taxpayer to raise a defence with respect to the information exchanged.

In determining whether a retroactive exchange of information should be allowed, it could be relevant to consider whether the taxpayer had a reporting obligation in the other state which the taxpayer has not fulfilled. If the taxpayer should have known about such obligation, this would imply that the exchange of information does not alter previous legal consequences known by the taxpayer (i.e. the principle of legal certainty is satisfied).

A statute of limitations provision is incorporated in the Brazilian Tax Code (see Article 173). This provision restricts the tax authorities from requesting information from taxpayers, either to charge taxes or to reassess, after a determined period of time (generally, five years). ${ }^{28}$ The Brazilian Tax Code does not specifically regulate the application of these provisions in the context of exchange of information procedures.

The relevant section of the internal manual of the Brazilian Revenue Service provides as follows:

The statute of limitations rules vary from country to country, and this is an important aspect to be considered when negotiating a TIEA. The base period also varies, and may not correspond to the calendar year. Therefore, it may happen that a request for exchange cannot be answered due to limitations imposed on the other tax administration.

These aspects should be taken into account when answering a request from a foreign administration and priority should be given to situations involving statute of limitations. (authors' translation) ${ }^{29}$

Taking into account this extract, for Brazil (when Brazil is the requesting party (paragraph 1)), the foreign administration may be unable to answer due to the statute of limitations in that state. Should Brazil be the requested

\section{Notes}

27 The principle of legal certainty basically intends to protect taxpayer confidence in an existent juridical situation. H. Avila, Certainty in Law 134-135 (Springer 2016), indicates:

By ordaining that 'the law shall not prejudice acquired rights, completed legal acts and res iudicata' (Art. 5, XXXVI), the Constitution protects legal certainty in the efficacy of one of its partial elements - reliability of the legal order. The protection of acquired rights, completed legal acts and res iudicata is a manifestation of the principles of protection of trust and good faith, which in turn translate the reflexive efficacy of the legal certainty principle oriented to a specific subject and a specific concrete case. By protecting these rights, it is as if through a rule the Constitution guaranteed the reflexive efficacy of the objective principle of legal certainty, applying it so as to uphold something won through law in the past. This rule governs the past-oriented subjective aspect of a principle which in addition to its objective dimension protects supra-individual interests, and may even oppose a given individual interest, as when a subjective right expires owing to limitation or prescription for lack of use. Thus the Constitution provides in some sense a 'guarantee of the past', as noted by Carvalho and Carrazza. In other words, express protection for these rights ... shows that the Constitution assures legal certainty, as certainty of law and certainty through law, for any citizen with regard to the state and to be realized by the state by means of rules, acts and procedures to enforce the individual rights arising from the reflexive efficacy of certainty as an objective principle of the legal order.

28 There is a clear exception in the Brazilian Tax Code (Art. 150(4)) to the five-year statute of limitations. This refers to cases of fraud or simulation, which can be assessed by tax authorities even in a period longer than five years.

29 Manual for Exchange of Information with Foreign Countries (Manual de Intercâmbio de Informações com o Exterior) issued by the Brazilian Revenue Service (edition Apr. 2008), at 35 . 
state (paragraph 2), it is not that clear whether the reference in the manual is made to the Brazilian statute of limitations or to the other country's statute of limitations. In any case, paragraph 1 indicates that the statute of limitations of the requested state is an important issue. If the Brazilian tax authorities recognize that the other country ought to observe its own statute of limitations, it is reasonable to interpret that the same applies to Brazil when it is requested to exchange information. However, there is no official confirmation as to whether this five-year limit is effectively observed by Brazil.

From a Brazilian perspective, the time limit to exchange tax information may be impacted by the statute of limitations rules (generally, five years) and, thus, requests after that date from another country may not be fulfilled by Brazil. On the contrary, requests before the expiration of the statute of limitations may be fulfilled even if they relate to taxable periods before the treaty came into force.

\section{I.3 Practice of the Brazilian Tax Authorities}

While certain Brazilian TIEAs may provide for a retroactive application of its exchange of information provisions (which seems to indicate a willingness of the tax authorities to exchange information retroactively), there is no indication that such retroactive exchange of information has actually occurred in Brazil at the time of writing. Thus, it remains unclear whether information actually exchanged by the Brazilian tax authorities has related to periods before the entry into force date of the TIEA.

\subsection{Colombia}

\subsection{Review of TIEAs Entered into by Colombia}

As at 11 November 2017, Colombia had signed TIEAs with Barbados, Curacao, the United Arab Emirates (UAE) and the United States, but only the TIEA with the United States had entered into force (on 30 April 2014). Colombia was also negotiating TIEAs with seven countries, namely Bermuda, Cayman Islands, Costa Rica, Guernsey, Kuwait, Panama and Qatar. This review does not include the TIEA entered into with Curacao, as the text was not available in the IBFD Treaty Database as updated as at 11 November 2017.

The TIEA with the United States establishes its entryinto-force rules in Article 7, under which the 'Agreement shall enter into force upon an exchange of notes by the duly authorized representatives of the contracting states by which they confirm their mutual agreement that both sides have met the constitutional and legal requirements necessary to effectuate this Agreement'. The TIEAs with Barbados and the UAE follow a similar approach, establishing that the TIEA 'shall enter into force on the date in which the later of the notifications has been received'.

The have-effect rules included in the TIEAs with Barbados, the UAE and the United States can be classified in Group A, as they may allow a retroactive application of the provisions of the TIEA.

Under the have-effect rule included in the TIEA between Colombia and the United States, ${ }^{30}$ the TIEA will not apply to information that is barred by the statute of limitations rules of the requesting state. Under this provision, the 'Agreement shall not apply to the extent that an action or proceeding concerning taxes covered by this Agreement is barred by the statute of limitations of the Applicant State'.

This TIEA does not follow the OECD Model TIEA, as it refers only to the statute of limitations rules of the applicant state (i.e. the state requesting the information), without establishing temporal limitations applicable to information concerning taxes prior to the date on which the TIEA enters into force. Thus, this TIEA may have a retroactive effect.

The have-effect rules included in the TIEAs with Barbados $^{31}$ and the $\mathrm{UAE}^{32}$ provide that the TIEAs have effect for information regarding taxable periods or charges to tax prior to the entry into force of the TIEA, provided that such information is available and that the request for information is submitted in accordance with the statute of limitations of the requesting state. ${ }^{33}$ These have-effect rules provide as follows:

The Contracting Parties shall exchange information, for requests made on or after the date of entry into force, regarding taxable periods prior to the entry into force of this Agreement, or where there is no taxable period, regarding charges to tax arising prior to the entry into force of this Agreement, provided that such information is available. The requested information shall correspond to tax liabilities that are reviewable by the tax authorities of the requesting Party according to its statute of limitations.

The availability of information is regulated in both the TIEA with Barbados and the TIEA with the UAE, ${ }^{34}$ establishing that the requested country is not obliged to provide

\section{Notes}

30 Art. 2(3) TIEA between Colombia and the United States.

31 Art. 12(3) TIEA between Colombia and Barbados.

32 Art. 11(3) TIEA between Colombia and the United Arab Emirates.

33 The TIEA between Colombia and Barbados has a protocol, which clarifies that the period of the statute of limitations rules referred to in Art. 11 will be limited to two years.

34 Art. 2 of the TIEAs signed by Colombia with Barbados and the UAE. 
information that is neither held by the tax authorities nor in the possession of or under the control of a resident or nonresident person over which it is able to exercise jurisdiction. Such provision was not included in the TIEA with the United States.

These TIEAs clearly establish that, provided that the exchange of information request is made after the entry into force of the particular TIEA, such request may cover not only information concerning events prior to the entry into force of the TIEA, but also information concerning taxable periods or charges to tax prior to such date. This can be considered a far-reaching application of a TIEA.

From the above, one can conclude that the have-effect rules included in the TIEAs signed by Colombia with Barbados and with the UAE may allow for a retroactive application of the exchange of information provisions, provided that certain conditions are met. The relevant conditions are availability of the information and that the statute of limitations of the requesting country has not expired.

\subsubsection{Legal Policy Considerations}

There is a Constitutional prohibition of retroactivity in taxation, but the Colombian tax authorities have taken the view that this prohibition refers only to substantive rules, and not to TIEAs, which may be considered as procedural rules. The courts have repeatedly held that procedural rules are not affected by the prohibition of retroactivity, and they have further ascertained that substantive aspects are those that concern the taxable amount, the triggering event or taxable subjects. ${ }^{35}$

As previously reviewed, certain TIEA provisions can be considered to have a substantive character, as they concern the determination of the taxable amount. This could provide a basis for challenging the position of the tax authorities, but it is considered unlikely that the courts would accept the nature of TIEA provisions as substantive, as this would invalidate exchange of information conducted prior to the ruling.

The prohibition of retroactivity in a TIEA context has been interpreted to restrict exchange of information requests concerning taxable years that are no longer available for audit by the local tax authorities based on the statute of limitations rules, which establish a two-year limit if a tax return has been filed or five-year limit if a tax return has not been filed or has been filed with tax losses. By contrast, a retroactive request for the exchange of information for taxable years that are still open for review ${ }^{36}$ will be allowed, unless the states have explicitly restricted the possibility to exchange that information in the respective TIEA.
When receiving a request to exchange information from another state, Colombia does not look at the timing of the taxable action or event to which the information refers, but rather at the timing of the supply of the information by the taxpayer or the time the information was obtained by the tax authorities. When the information is not held by the tax authorities in Colombia at the time it receives the request, Colombia will review whether it could obtain that information in accordance with its domestic statute of limitations rules (i.e. five years from the date on which the return should have been filed). If this period has elapsed, Colombia will deny the petition to exchange information on the grounds that it does not have the authority to obtain said information.

In cases where a taxpayer was not required to file a tax return, Colombia could still consider requesting the information from the taxpayer. However, such procedure would be considered extraordinary and the costs would be transferred to the requesting state. The prohibition of retroactivity stems from the right to legal certainty in taxation, as the taxpayer has the right to enjoy the economic consequences of its transactions as planned under the enforceable laws. An exception to the prohibition of retroactivity applies in the context of TIEAs, provided that the requested information concerns a fiscal year that is still open for review. It is submitted that the exception is based on the fact that TIEAs may be considered as procedural rules and that a future audit could profit from that information. The policy behind this rule is the useful-effect policy, which states that contracting parties will make the effort to exchange information only if the requesting party can guarantee that it will be useful for a domestic audit.

\subsubsection{Practice of the Colombian Tax Authorities}

As mentioned in section 4.2.1, only the TIEA with the United States is currently in force in Colombia. In relation to this TIEA, the Colombian research unit reported that, at the time of preparing the questionnaire on this topic, no request had been received by Colombia from the United States to exchange information that may be considered barred by the US statute of limitations rules. The practice of the Colombian tax authorities regarding this TIEA is that information will be exchanged depending on whether it is open for review in accordance with the statute of limitations rules of the state requesting the information (i.e. the requesting state). It is not relevant whether the information concerns a taxable action, taxable event or taxable period prior to the TIEA.

For requests from the United States, the US statute of limitations rules are applicable. The Colombian statute of

\section{Notes}

35 CO: Constitutional Court, Case C-1251 (D-3591) (C.Const.Col. 2001) \& Case C-430 (D7645) (C.Const.Col.2009).

36 If the tax authorities have initiated an audit, the statute of limitations is interrupted and the information is subject to exchange until the case is closed or sent to the judiciary. 
limitations rules are applicable for requests of information by Colombia. The Colombian statute of limitations rules establish a two-year limitation period if the taxpayer filed a tax return ${ }^{37}$ or five years if the taxpayer did not or if the taxpayer reported tax losses. Even if a tax case is closed for Colombian tax purposes, information will be exchanged by Colombia within these time limits.

The US TIEA can be considered an exception to the administrative practice, and will likely require more effort from Colombia to access the information because the information is maintained by the tax administration only within the timeframe of the statute of limitations, which is shorter in Colombia than in the United States.

\subsection{South Africa}

\subsection{Classification of TIEAs Entered into by South Africa}

As at 11 November 2017, South Africa had entered into TIEAs with twenty-one countries, of which nineteen TIEAs had entered into force, namely those with Argentina, the Bahamas, Barbados, Belize, Bermuda, Cayman Islands, Cook Islands, Costa Rica, Gibraltar, Grenada, Guernsey, Jersey, Liberia, Liechtenstein, Monaco, Samoa, San Marino, St. Kitts and Nevis and Uruguay. The TIEAs that were signed, but not in force as at 11 November 2017, were those with the Dominican Republic and Turks and Caicos Islands.

In addition, eleven TIEAs were under negotiation as at 11 November 2017, namely with Andorra, British Virgin Islands, Brunei, Isle of Man, Jamaica, Macau, Maldives, Marshall Islands, Panama, St. Lucia and St. Maarten.

The TIEAs entered into by South Africa have similar entry-into-force dates, which refer to the date on which the last contracting party provides written notification about completion of all legal formalities required for entry into force. ${ }^{38}$ By contrast, the TIEAs contain different have-effect rules, which - using the classification presented above - can be classified in Groups A, B, C and D, as follows:

- Group A: none of the TIEAs fall within this group;

- Group B: the TIEA with Liechtenstein has been classified in Group B. This TIEA is applicable to any request after the TIEA enters into force, but only in respect of taxable periods beginning on or after that date. This TIEA may also cover information regarding actions or events that occurred before the TIEA entered into force, but which have relevance for determining the tax liability for taxable years after such date;

- Group C: the TIEA with the Bahamas has been classified in Group C. This TIEA provides that, for non-criminal tax matters, the TIEA will have effect on its date of entry into force (25 May 2012), but only in respect of taxable periods beginning on or after that date or, where there is no taxable period, all charges to tax arising on or after that date. However, for criminal tax matters, this TIEA provides that it will have effect on its date of entry into force (25 May 2012), covering information concerning taxable periods beginning on or after 1 of January 2004 or, where there is no taxable period, for all charges to tax arising on or after 1 of January 2004; and

- Group D: most of the TIEAs are included in this group, namely those with Argentina, Barbados, Belize, Bermuda, Cayman Islands, Cook Islands, Costa Rica, Dominican Republic, Gibraltar, Grenada, Guernsey, Jersey, Liberia, Monaco, Samoa, San Marino, St. Kitts and Nevis, Turks and Caicos Islands and Uruguay.

The have-effect rules included in these TIEAs establish that, for criminal tax matters, the TIEA will have effect on its date of entry into force, without specifying whether the request may refer to a taxable period before such date. For non-criminal tax matters, the TIEA specifies that it will have effect from that date, but only concerning information relevant for taxable periods beginning on or after that date or, where there is no taxable period, for all charges to tax arising on or after that date.

From the classification above, one can conclude that some TIEAs entered into by South Africa may have retroactive effects. This refers, especially, to the TIEAs in Groups C and D for information requests concerning criminal tax matters.

\subsubsection{Legal Policy Considerations}

In terms of the South African common law, it is generally understood that statutes are not to be construed to operate retroactively, unless an express or implied intention exists to the contrary. ${ }^{39}$ In Bellairs $v$. Hodnett and Another, ${ }^{40}$ the following was stated:

There is a general presumption against a statute being construed as having retroactive effect and even where a

\section{Notes}

37 A Colombian tax return is required in most instances.

38 South Africa has enacted two TIEAs with a retroactive date of entry into force, namely those with Bermuda and the Bahamas. This implies that the notified 'entry into force' date predates the publication of the TIEA in the Government Gazette.

39 ZA: Adampol (Pty) Ltd v. Administrator, Transvaal, 4 All SA 776 (AD) (22 May 1989), at 783; ZA: Unitrans Passenger (Pty) Ltd t/a Greybound Coach Lines v. Chairman, National Transport Commission, 3 All SA 365 (A) (28 May 1999), para. 12; ZA: Curtis v. Johannesburg Municipality, TS 308 (29 May 1906), at 311; ZA: Mohamed NO v. Union Government, AD (11 Jan. 1911), para. 8, at 1; ZA: Bellairs v. Hodnett and Another, 1978 (1) SA 1109 (A) (2 Dec. 1977), para. 1148F-G. See also J. C. Taljaard, Geld die gewone reëls en beginsels van wetsuitleg by die uitleg van belastingwetgewing, Thesis M.Comm (Taxation) Stellenbosch University (Dec. 2001), s. 2.4.1, citing ZA: Principal Immigration Officer v. Pushotam, 1928 AD 435443 (22 June 1928) and ZA: Jockey Club of SA v. Transvaal Racing Club, 19591 SA 441 A 451 (11 Dec. 1958).

40 ZA: Bellairs v. Hodnett and Another, 1978 (1) SA 1109 (A) (2 Dec. 1977), para. 1148F-G. 
statutory provision is expressly stated to be [retroactive] in its operation it is an accepted rule that, in the absence of contrary intention appearing from the statute, it is not treated as affecting completed transactions and matters which are the subject of pending litigation.

The rationale behind this presumption is the need for legal certainty. The rationale can also be said to be that all persons subject to legislative provisions should be treated fairly, irrespective of the prospective or retroactive nature of the legislative provision in question. ${ }^{41}$ There is, however, no express rule that prevents the South African Parliament from amending or enacting legislation with retroactive effect, if it specifically so determines. $^{42}$

In a TIEA context, the South African government does not refuse a retroactive application of tax information exchange provisions or TIEAs in general. However, a retroactive TIEA will be refused if the retroactivity in question infringes upon the rights of a person on an unacceptable level under the Constitution.

In South Africa, taxpayer rights are not absolute (i.e. they may be limited), and are subject to the so-called 'limitation clause' under section 36 of the South African Constitution, which provides that 'the rights in the Bill of Rights may be limited only in terms of law of general application to the extent that the limitation is reasonable and justifiable in an open and democratic society'.

It is submitted by the South African research unit that the standard of prohibiting retroactive TIEAs would differ depending on whether the information is in the possession of competent authorities. One can conclude that retroactive TIEAs may be accepted if the competent authorities have the information readily available, and be refused where such information must be retrieved from a private financial institution.

With regard to matters not dealing with criminal liability, the presumption against retroactivity has not been addressed by the South African Constitution and, thus, there is no real prohibition on the powers of the government to enact retroactive legislation. Retroactivity in relation to matters dealing with criminal liability needs to be considered in light of section 35(3)(1) of the South African Constitution, which provides as follows:

Every accused person has a right to a fair trial, which includes the right not to be convicted for an act or omission that was not an offence under either national or international law at the time it was committed or omitted.

Further, a specific provision of the South African Constitution specifically allows the retroactive application of legislation in criminal matters. In this regard, section 35 (3)(n) of the South African Constitution provides as follows:

Every accused person has a right to a fair trial, which includes the right to the benefit of the least severe of the prescribed punishments if the prescribed punishment for the offence has been changed between the time that the offence was committed and the time of sentencing.

Section 35(3)(1) of the South African Constitution states that an accused person cannot be convicted for an act or omission if that act or omission was not an offence at the time it was committed or omitted. It is therefore (with regard to criminal conduct) in line with the broader common law view on retroactivity. On the other hand, section 35(3)(n) of the Constitution provides for the retroactive application of a statute that reduces a convicted person's criminal liability.

It is therefore clear that there are no specific constitutional rules directly prohibiting retroactive TIEA provisions.

\subsubsection{Practice and Case Law of the South African Tax Authorities}

The South African tax authorities (the South Africa Revenue Service, SARS) and courts have been involved in cases discussing the possibility of applying provisions for assistance in the collection of taxes in relation to tax liabilities that arose before such provisions were included in the tax treaty.

The first is the Ben Nevis case, ${ }^{43}$ in which the SARS requested that the UK tax authorities assist them in the collection of a tax claim against a British Virgin Islands company, Ben Nevis (Holdings) Limited (Ben Nevis), which was owned and controlled by a South Africanbased businessman, David King. The request was based on Article 25A of the tax treaty between Australia and South Africa. The tax treaty was originally entered into in 2002, but was amended by a Protocol signed in 2010, which replaced the original tax information exchange provision with a new tax information exchange provision (Article 25) and inserted a new provision (Article 25A) on assistance in the collection of taxes.

\section{Notes}

41 L. M. Du Plessis, Statute Law and Interpretation, in Introduction to the Law of South Africa 341 (C. G. van der Merwe \& J. E. Du Plessis eds, Kluwer Law International 2004).

42 This is equally the case for 'enacting' TIEAs. A TIEA enters into force in South Africa only after it has been approved by both Houses of Parliament, as well as being published in the Government Gazette. Only thereafter will the TIEA become law as if enacted as part of the Income Tax Act.

43 UK: Ben Nevis (Holdings) Limited (1) and Metlika (Trading) Limited (2) v. Commissioners for H M Revenue and Customs, EWCA Civ 578 (23 May 2013) 
As the British Virgin Islands is a dependent territory of the United Kingdom, the UK tax authorities accepted the request and initiated a tax proceeding against Ben Nevis for the sum that it had been held to owe the SARS in taxes for the 1998, 1999 and 2000 years of assessment, plus penalties and interest. Ben Nevis questioned the validity of the proceedings, arguing that the new mutual assistance provisions included by the 2010 Protocol may be applied only to cases regarding tax assessment years after the provisions entered into force (2010).

The UK High Court took the position that once the 2010 Protocol entered into force, the mutual assistance provision included in Article 25A would apply from the entry into force date of the treaty (2002), to all tax claims regardless of when they arose. The validity of the proceedings would only be subject to the requirement that the request for assistance be made on or after the entry into force of the 2010 Protocol. The UK High Court considered this to be in accordance with the OECD Model Tax Convention, on which both Article 25A and the tax treaty are based.

The UK High Court also established that the purpose of the 2010 Protocol was to assist international tax enforcement. This does not suggest any logical or policy reason for imposing a temporal limitation on the scope of Article $25 \mathrm{~A}$, which gave it retrospective effect but excluded tax years arising earlier than the coming into effect of the 2002 tax treaty.

The decision of the High Court was confirmed by the UK Court of Appeal. The Court of Appeal applied the distinction between procedural rules and substantive rules in relation to the mutual assistance provisions included in Article $25 \mathrm{~A}$ and exchange of information provisions in general, and concluded that such administrative provisions are procedural rules that are applicable as soon as they enter into effect, which are not required to be limited temporally in their application to particular years of assessment. Consider the following relevant sections of the decision of the UK Court of Appeal in the Ben Nevis case:

23. Whereas provisions which modify tax changes need to be linked to the relevant tax period so as to ensure a smooth transition from the existing rules to the new rules, there is no need to make similar provision for administrative provisions such as Article 25A which may, without difficulty, be brought into effect as soon as the Protocol comes into effect.

24. This reading of the provisions is also consistent with the objective of the Protocol which ... is to assist international tax enforcement. This purpose would be obstructed by limiting Article 25A in the manner proposed by the Appellants ...

29. ... The substantive provisions of the Convention which address issues of double taxation and which modify liabilities clearly need to be related to the relevant tax periods for the system to be workable. By contrast, there is no particular reason why exchange of information provisions such as Article 25, which are not concerned with the modification of tax charges, require to be limited temporally in their application to particular years of assessment. Information can be effectively exchanged without the process being related to defined periods of liability to taxation. ${ }^{44}$

Another relevant case is Krok, in which the Australian Tax Office (ATO) requested assistance from the SARS for tax collection and preservation of assets of the taxpayer, Mark Krok. Mr Krok was originally a South African tax resident person, but migrated to Australia and then subsequently to the United Kingdom. Funds and property still remained in South Africa due to exchange control regulations (i.e. blocked funds).

The ATO request was based on the provision concerning assistance in the collection of taxes (Article 25A) of the tax treaty between South Africa and Australia. This provision was included in the tax treaty by the Protocol concluded on 31 March 2008, which entered into force on 12 November 2008. The case was initially decided by the High Court of South Africa on 31 January 2014, ${ }^{45}$ and was upheld by the Supreme Court of Appeal, which delivered its judgment on 20 August 2015. ${ }^{46}$

The main argument of the taxpayer regarding retroactivity was that, as the tax debts owing to the ATO related to the years 30 June 2004 to 30 June 2009, the Protocol and Article 25A of the tax treaty could be invoked by the tax authorities only for the taxes arising from years commencing from 1 of July $2009 .^{47}$

The South African High Court concluded that Article 25 contains no temporal limitation. Having regard to Article 2(4) of the tax treaty, the taxes to which the treaty will apply are 'taxes of every kind and description'. Once the new Article 25 came into operation, all information

\section{Notes}

44 Ben Nevis (Holdings), paras 23, 24 \& 29.

45 For a comprehensive discussion of the High Court decision, see C. West \& J. Roeleveld, South Africa: Retrospectivity of Treaty Clauses Regarding Assistance in the Collection of Taxes and the Preservation of Assets, in Tax Treaty Case Law around the Globe 2015 (M. Lang et al. eds, IBFD 2016).

46 Krok v. CSARS, 20230/2014 and 20232/2014 ZASCA 107 (20 Aug. 2015).

47 The taxpayer used as an argument the date that the Protocol has effects for Australian taxes. Under Art. 13(2) of the Protocol, the Protocol will have effects, in the case of Australia, 'in respect of income, profits or gains of any year of income beginning on or after 1 July in the calendar year next following the date on which the Protocol enters into force'. 
concerning taxes of every kind and description will be exchanged.

Furthermore, the South African High Court referred to the arguments presented by the taxpayer on the interpretation of Article 2. The taxpayer argued that only information concerning taxes arising after 1 July 2009 could be exchanged. The South African tax authorities argued that this could not have been the intention, if regard were given to the fact that under the previous Article 25, there was no limitation as to the time period in relation to which information could be exchanged.

In this regard, the South African High Court referred to Article 13(2)(d) of the Protocol, under which the Protocol entered into force on the date of the last notification, and thereupon the Protocol will have effect, for purposes of Article 25 A, from a date to be agreed between the parties by exchange of diplomatic notes. According to the South African High Court, this meant that Article $25 \mathrm{~A}$ was introduced into the treaty with effect from a future date to be agreed (which was 1 July 2010) and, that once Article 25 A came into effect, under its terms, it had no temporal limitation. Based on this, the High Court held that, when Article 25A came into effect and operation on 1 July 2010, it applied to a revenue claim, being a claim in respect of 'taxes of every kind and description', under Article 2(4).

Furthermore, the South African High Court established that, as there was no specification as regards the period for which the taxes relate to, this meant that assistance would be granted in the future for already existing obligations. This interpretation follows the argument asserted by the SARS, which the South African High Court considered correct and logical having regard to the treaty provisions and their purpose.

The South African High Court based its judgment on the agreement of the contracting states in this regard. As the contracting states did not establish whether the assistance in collection of taxes must refer to previous or future tax liabilities, the High Court concluded that the assistance should cover any existing obligation at the time the provision of assistance has effect.

The judgment of the High Court was appealed by $\mathrm{Mr}$ Krok, but the appeal was dismissed by the Supreme Court of Appeal. The judgment of the Supreme Court affirmed the reasoning of the High Court, highlighting that 'the effect of Article $25 \mathrm{~A}$ is prospective, as it could only be invoked when the relevant countries have agreed and its provisions came into force. Tax claims which arose in the past in respect of which assistance was sought would also be covered. ${ }^{48}$

In addition to the reasons mentioned by the High Court, the Supreme Court also referred to the comments of the UK High Court concerning the procedural nature of the administrative provisions such as Article 25A, and indicated that such view appropriately conceptualizes the tax treaty and the meaning and purpose of Article 25A and, thus, there is clearly no basis to construe Article 25A as having temporal limitations. ${ }^{49}$

Even though the position adopted by the South African Courts in the Krok case refers to the interpretation of a tax treaty, such position may be similarly applied for interpreting most South African TIEAs, especially those classified in Group D, which do not contain clear rules regarding their temporal application to requests concerning criminal matters. As indicated in section 4.3 .1 above, these TIEAs establish that, for criminal tax matters, they will have effect from their date of entry into force, without specifying whether the request may refer to information concerning a taxable period or charges to tax prior such date. By contrast, for requests concerning non-criminal matters, these TIEAs limit their temporal application to information relevant for taxable periods or charges to tax arising on or after the date of entry into force of these TIEAs.

Based on the judgments above, the TIEAs in Group D may be interpreted as allowing exchange of any information involving criminal tax matters only, without being limited by the taxable period of (or timing of the tax) to which the actions or events the information refers.

\subsection{Uruguay}

\subsection{Review of TIEAs Entered into by Uruguay}

As at 11 November 2017, Uruguay had signed TIEAs with Argentina, Australia, Brazil, Canada, Chile, Denmark, Faroe Islands, France, Greenland, Guernsey, Iceland, the Netherlands, Norway, South Africa, Sweden and the United Kingdom, of which only one was not yet in force, namely the TIEA with Brazil. In addition, Uruguay is negotiating a TIEA with Austria.

The review indicates that the entry-into-force rules are similar in the TIEAs signed by Uruguay. These rules provide that the date of entry into force is to be the date of the later notification by the contracting parties of the completion of the domestic procedures required for bringing the TIEA into force.

The have-effect rules are also similar in Uruguayan TIEAs and can be classified in Group D. These rules distinguish between criminal tax matters and other tax matters. For criminal tax matters, the TIEAs have effect on their date of entry into force, without specifying whether the request may refer to a taxable period or charge to tax arising before such date. For other tax matters, the TIEAs specify that they will have effect from that date, but only concerning information

\section{Notes}

\footnotetext{
48 Krokv. CSARS, supra n. 46, para. 40.

49 Ibid., para. 39
} 
(potentially, also for prior events) relevant for taxable periods beginning on or after that date or, where there is no taxable period, for charges to tax arising on or after that date.

The above may imply that Uruguayan TIEAs may have retroactive effects in relation to criminal tax matters, as they may allow the exchange of information relevant for taxable periods or charges to tax prior to their date of entry into force. These TIEAs should have no retroactive effect in relation to information requests covering noncriminal tax matters.

\subsubsection{Legal Policy Considerations}

Uruguay has no constitutional rules directly prohibiting retroactive TIEAs. However, such prohibition is indirectly derived from the principle of legal certainty, which is established in Article 72 of the Uruguayan Constitution.

The position of not allowing retroactivity may also be supported by domestic law. Under Law 18,331, information supplied to a public authority may be used only for the specific purpose for which the information was given. On such basis, the law in force at the moment of the supply of information constitutes a framework of possible purposes for use of the information. Consequently, if information is supplied at a moment when a TIEA is not in force, the information exchange with the other party to the agreement should not be considered to be included in the framework of possible purposes of the use of such information.

The position described above is connected with the concept of the safeguard of taxpayer rights in a tax proceeding, as it is based on the purpose of the supply of the information.

It is submitted that the determination of retroactivity, in Uruguay, is based on the date of the actual supply of the information (or the date the information should have been supplied) by the taxpayer to the public authority. The taxable period or timing of the tax charge to which the information refers to (either before or from the date on which the TIEA enters into force) does not seem to be relevant for this purpose.

\subsubsection{Practice of the Uruguayan Tax Authorities}

At the time of writing this article, the Uruguayan tax administration had not expressed a public opinion about whether it would accept a request for exchange of information concerning taxable periods or taxes prior to the entry into force of the applicable TIEA. This situation is a consequence of the short period that has passed since the entry into force of such TIEAs.

However, the Uruguayan tax administration has received some information requests from Argentina, in relation to both criminal tax matters and civil tax matters. In relation to the request concerning criminal tax matters, the Uruguayan tax administration did not provide the requested information because the TIEA was not in force at the time of the request. In relation to the four requests concerning civil tax matters, they were also rejected as the information referred to events concerning taxes prior to the date on which the TIEA entered into force.

\subsection{Main Findings}

The table below provides an overview of the classification of all the TIEAs entered into by the surveyed countries:

\begin{tabular}{lllll}
\hline & Brazil & Colombia & South Africa & Uruguay \\
\hline Group A & 2 & 3 & - & - \\
Group B & 2 & - & 1 & - \\
Group C & 2 & - & 1 & - \\
Group D & 4 & - & 19 & 16 \\
Total & 10 & 3 & 21 & 16 \\
\hline
\end{tabular}

As shown in the table, not all the surveyed countries have TIEAs in all the groups listed above. For example all Colombian TIEAs are within Group A. By contrast, all Uruguayan TIEAs are within Group D.

The review establishes that some TIEAs entered into by Brazil, South Africa and Uruguay follow the OECD Model TIEA and have expressly included provisions intended to restrict their retroactive application. Such provisions establish that the TIEAs have effect only in respect of information (including information on prior actions or events) relevant for taxable periods beginning on or after the date of entry into force of the TIEA or, where there is no taxable period, relevant for all charges to tax arising on or after that date.

By contrast, other TIEAs entered into by these three countries and the TIEAs entered into by Colombia may allow a retroactive application of their exchange of information provisions, by either having included provisions allowing exchange of information, provided that the request is done after the date on which the TIEA enters into force (regardless of whether it concerns to prior taxable periods or charges to taxes), or by allowing such retroactive application only for requests concerning criminal tax matters.

The review has also shown that the country practice of the surveyed countries differ in relation to allowing the retroactive application of a TIEA under domestic law.

Uruguayan law takes a different approach from the other surveyed countries focusing on legal limitations for the use of 
information provided to public authorities. Under Uruguayan domestic law, information may be used only for the specific purpose for which it was provided, and such purpose is determined by the law in force at that moment. Provided that the specific TIEA does not establish otherwise, the Uruguayan tax authorities may not exchange information previously provided by a taxpayer if the TIEA was not in force at the time the information was provided. The timing of the taxable period or of the tax charge may not be relevant for this purpose.

The other three countries (Brazil, Colombia and South Africa) may generally allow certain cases of retroactive exchange of information based on their domestic law and policy. This is supported in some cases by the understanding that TIEA provisions may be regarded as procedural rules and, thus, a retroactive application may be allowed.

The Colombian and Brazilian research units determine that their obligations to exchange information are restricted by domestic statute of limitations rules. This implies that information may be exchanged by the requested countries if the statute of limitations period of the requesting state has not expired. These countries use as a reference for applying these rules the time the information was provided by the taxpayer (or needed to be provided), regardless of the potential retroactive effect derived from exchanging information relevant for a taxable period or tax charge prior to the date on which the TIEA enters into force.

The Brazilian and South African research units mention that a retroactive exchange of information should not violate taxpayer rights to an unacceptable level and that the level of violation of rights should be evaluated in relation to the specific case.

Another relevant element for Brazil, Colombia and South Africa is that a retroactive exchange of information should be allowed if the taxpayer knew that an obligation existed in another state. In this way, it is accepted by these countries that such retroactive application of a TIEA should not be considered as altering the legal consequences that were already known by the taxpayer at the time the TIEA entered into force.

A final comment refers to the extent of the obligations of the state. Brazil and South Africa appear to be in favour of allowing a retroactive TIEA application in cases when the competent authorities have the information readily available, and to reject such retroactive application where such information has to be obtained from a public authority or financial institution. This is subject to the condition in both states of compliance with due administrative process.

\section{TRANSPARENCY AND GOOD TAX GOVERNANCE}

\section{I The Notion of Transparency as Predictability}

The standard of transparency and exchange of information has been developed by the OECD in its Model Tax Treaty and in the OECD Model TIEA. The OECD has not provided a general definition of the term 'transparency', but it has identified certain essential elements that need to be complied with by countries to implement this standard. Such elements are categorized into three groups: availability of information, access to information and mechanism for exchanging information. ${ }^{50}$ The United Nations has also proposed a definition of transparency, under which, 'Transparency means ... that information is freely available and directly accessible to those who will be affected by such decisions and their enforcement. It also means that enough information is provided and that it is provided in easily and understandable forms and media'. ${ }^{51}$

The notion of transparency following the definitions above from the OECD and the United Nations seems to mainly focus on transparency as access to all relevant information concerning the taxpayer. Such notion of transparency may support that countries should cooperate with each other and exchange information that they have available, even if such information relates to taxable periods or charges to tax before a TIEA enters into force.

This article will consider an approach to transparency that goes beyond access to information, to focus on the nature of the system of tax governance itself. This approach will consider that existing laws (e.g. laws implementing TIEAs in domestic law) provide a basis for the legitimization of public decisions and that they cannot be applied retroactively. As proposed by Schnell, 'transparency can be seen as predictable decision making according to clear and publicly-known or knowable rules'. ${ }^{52}$ Schnell also proposes that 'transparency denotes government according to fixed

\section{Notes}

50 OECD, Global Forum Terms of Reference, Background Brief, Annex I (Nov. 2013), at 6, http://www.oecd.org/tax/transparency/global_forum_background\%20brief.pdf (accessed Nov. 2017). See also OECD Country Peer Reviews of the Global Forum on Tax Transparency and Exchange of Information, from which the notion of transparency resulted indirectly since 2006, and the PhD thesis of A. Turina, Information-Based Administrative Cooperation Consolidating Standards, Emerging Actors and Evolutionary Perspective, Boconi University (2012-2013), in which, at 28-32, the elements of transparency are discussed. For further development of the notion of transparency, see A. Turina, 'Visible, Though Not Visible in Itself: Transparency at the Crossroads of International Financial Regulation and International Taxation, 8(3) World Tax J. 392-397 (2016).

51 This definition of transparency is proposed by the United Nations, the Economic and Social Commission for Asia and the Pacific in UN-ESCAP, What Is Good Governance, http://www.gdrc.org/u-gov/escap-governance.htm (accessed 31 Jan. 2018).

52 S. Schnell, From Information to Predictability: Transparency on the Path to Democratic Governance, Paper presented at the 4th Global Conference on Transparency Research (4-6 Jun. 2015), http://www.transparency.usi.ch/sites/www.transparency.usi.ch/files/media/schnell_from_information_to_predictability_-_transparency_on_the_path_to_demo cratic_governance.pdf (accessed Nov. 2017). 
and published rules, on the basis of information and procedures which are accessible to the public'. ${ }^{53}$

The dimension of 'transparency as predictability' requires clear and publicly-known rules which are not applied retroactively. The OECD has, for example, indicated that:

one key element is that the new laws or other parts of the legal system are not put into effect retr.oactively, and that no entity or citizen should suffer disadvantages because of retroactive implementation of new rules. All companies should be able, on equal footing, to know the conditions in which they operate and to prepare themselves sufficiently in advance, when changes are upcoming. $^{54}$

As established in the General Report delivered at the 69th Congress of the International Fiscal Association (IFA) in 2015, retroactive tax law undermines legal certainty, interferes with the legitimate expectations of taxpayers, and damages respect for the rule of law'. Baker and Pistone submitted in this general report that the prohibition against retroactive tax law should be recognized as a minimum standard, subject to limited exceptions in the public interest, such as abuse. ${ }^{55}$

This broader notion of transparency as predictability supports that TIEAs should not be applied retroactively, but only for exchanging information relevant for taxable periods or charges to tax from the date on which the TIEA enters into force.

\subsection{Retroactivity and the Fundamental Rights of Taxpayers}

In accordance with ECJ case law, the principle of transparency and good governance cannot be interpreted broadly as prohibiting any type of retroactivity. Retroactive measures have been accepted by the ECJ if (1) the purpose of the measure so requires and (2) the legitimate expectations of those affected are duly respected. ${ }^{56}$ Both conditions are closely linked and represent the conflicting interests that are involved. ${ }^{57}$ It is necessary that there be a balancing between the general interests of the community (represented by the purpose of the measure) and the requirements for protection of legitimate expectations and the individual's fundamental rights. $^{58}$

According to the OECD Model TIEA, the purpose of a TIEA is to promote international cooperation in tax matters by providing states with information that is foreseeably relevant to the determination, assessment and collection of taxes; the recovery and enforcement of tax claims; or the investigation or prosecution of tax matters. ${ }^{59}$ This purpose may support a retroactive application of TIEA provisions allowing for the exchange of any information, even if it is relevant for taxable periods or tax charges before the TIEA entered into force.

However, one can question whether such retroactive application might be contrary to the principle of protection of legitimate expectations of taxpayers and the fundamental rights of taxpayers. The protection of legitimate expectations 'requires public authorities to exercise their powers over a period of time in such a way as to ensure that "situations and relationships" lawfully created under Community law are not affected in a manner which could have not been foreseen by a diligent person'. ${ }^{60}$

To determine whether a retroactive TIEA application may be contrary to the principle of protection of legitimate expectations, it should be assessed whether such retroactive application may infringe the rights of taxpayers. This assessment should consider potential negative consequences for taxpayers derived from such retroactive application. Expectations to evade taxes in another country will not be deemed legitimate.

This article submits that legal certainty and predictability are the basis of a legal system and provide the framework for an effective exercise of the fundamental right of taxpayers. A basic right of taxpayers which is present in all OECD countries is the right to certainty. ${ }^{61}$ According to the OECD, 'it is a goal that taxpayers should be able to anticipate the consequences of their ordinary personal and business affairs'. ${ }^{62}$

\section{Notes}

53 Ibid., at 8 .

54 OECD, Investment Policy Reviews: Ukraine 2002 - Progress in Investment Reform 152-153 (2002)

55 P. Baker \& P. Pistone, IFA Cabiers 2015 - Volume 100b. The Practical Protection of Taxpayers' Fundamental Rights, General Report 67 (IBFD 2015).

56 For relevant case law of the ECJ, see e.g. Finanzamt Sulingen v. Walter Sudbolz, Case C-17/01, ECR I-4243 (29 Apr. 2004), para. 33; Racke v. Hauptzollampt Mainz, Case 98/78, ECR 69 (16 June 1998), para. 20; Netherlands v. Council, Case C-110/97, ECR I-8763 (30 Apr. 1996), para. 151; Stichting 'Goed Wonen' v. Staatssecretaris van Financiën, Case C-376/02, ECR I- 3445 (26 Apr. 2005).

57 T. Tridimas, The General Principles of EU Law, 256 (2d ed., Oxford EC Law Library 2006).

58 Ibid.

59 The purpose of a TIEA is established in the introduction and Art. 1 of the OECD Model TIEA.

60 Tridimas, supra n. 57, at 252

61 OECD, Committee of Fiscal Affairs, Forum on Tax Administration, Taxpayers' Rights and Obligations: Practice Note, Tax Guidance Series 3, https://www.oecd.org/tax/ administration/Taxpayers\%27_Rights_and_Obligations-Practice_Note.pdf (accessed 11 Nov. 2017).

62 Ibid., at 4 
Another fundamental right of taxpayers is the right to defence, which is generally considered a common constitutional right and safeguard of taxpayers in the surveyed countries. Such right may require that a tax audit follow a pattern that taxpayers can find in advance, for instance, from guidelines made public and periodically updated on the official website of the tax authorities. This will allow taxpayers to know how the tax will be assessed and enable them to timely exercise their right to defence within the audit procedures. ${ }^{63}$ If the pattern and legal framework change due to a retroactive TIEA, this could affect the right to defence of taxpayers.

The right to defence is recognized both in Article 8 of the American Convention on Human Rights (Pact of San Jose, Costa Rica) and in Article 7 of the African Charter on Human and Peoples' Rights (also known as the Banjul Charter).

A retroactive TIEA application may also infringe the right of taxpayers to provide evidence during a tax audit procedure. If, for example, a taxpayer on Day 1 knows that the taxpayer does not need to provide evidence of something, the taxpayer could, for instance, throw away a receipt that would otherwise perfectly prove a payment or the right to claim a tax exemption. However, if on Day 2 , the legal framework changes and retroactively, the taxpayer will no longer be able to prove what the taxpayer did in good faith.

In certain developing countries, a retroactive TIEA application may increase the risk of infringement of taxpayers' rights, such as the right to defence and the right to provide evidence to tax authorities. This may be due to, for example, tax authorities focusing on generating tax revenue, lack of capacity or less developed procedural rules on how to perform a tax assessment.

As recognized by Pistone, 'although exchange of information clauses are intended to facilitate mutual assistance between tax authorities, such exchange of information may directly affect the rights of taxpayers and this right should be effectively protected by an international legal instrument'. ${ }^{64}$

It was previously concluded that the purpose of a TIEA may require a retroactive application of TIEA provisions allowing for the exchange of information relevant for taxable periods or charges to tax prior to the date on which the TIEA entered into force. However, such retroactive application may not be in accordance with taxpayer rights and the principle of protection of legitimate expectations. Therefore, there is a need to balance the TIEA purpose against the legitimate expectations of taxpayers to determine whether a retroactive TIEA application can be justified.

The European Court of Human Rights (ECtHR) has provided guidelines on balancing the compatibility of retroactive measures with the right to property guaranteed in Article 1 of the First Protocol to the European Convention for the Protection of Human Rights and Fundamental Freedoms. ${ }^{65}$

In the M.A. case, ${ }^{66}$ for example, the ECtHR examined the compatibility of a retroactive Finnish tax statute with Article 1 of the First Protocol. ${ }^{67}$ The statute treated profits on stock options as income relating to employment. When the measure was working its way through the Finnish parliament, a number of employees made arrangements with their employers to accelerate the exercise date of their stock options in an attempt to avoid the new tax. The Finnish parliament decided to make the law retroactive to the date on which the bill was first introduced. When assessing the M.A. case, the ECtHR provided guidance in relation to the margin of appreciation of the states, stating as follows:

An interference, including one resulting from a measure to secure payment of taxes, must strike a 'fair balance' between the demands of the general interest of the community and the requirements of the protection of the individual's fundamental rights ... Furthermore, in determining whether this requirement has been met, it is recognized that a Contracting State, not least when framing and implementing policies in the area of taxation, enjoys a wide margin of appreciation and that the Court will respect the legislature's assessment in such matters unless it is devoid of foundation. ${ }^{68}$

The ECtHR concluded in this case that the taxpayers did not have a protected legitimate expectation. The aim of the retroactive measure was to ensure equal treatment of taxpayers: between those who did not bring forward the exercise date of the stock options, and those who had done

\section{Notes}

63 Baker \& Pistone, supra n. 55, at 90.

64 P. Pistone, Exchange of Information and Rubik Agreements: The Perspective of an EU Academic, 67(4/5) Bull. Int'l Tax'n 225 (2013).

65 This article does not take a position in relation to whether information can be protected by the right to property under the European Convention for the Protection of Human Rights and Fundamental Freedoms.

66 M.A. and 34 Others v. Finland, ECtHR, Case $27793 / 95$ (10 June 2003).

67 Art. 1 of the First Protocol provides as follows: 'Every natural or legal person is entitled to the peaceful enjoyment of his possessions. No one shall be deprived of his possessions except in the public interest and subject to the conditions provided for by law and by the general principles of international law.

The preceding provisions shall not, however, in any way impair the right of a State to enforce such laws as it deems necessary to control the use of property in accordance with the general interest or to secure the payment of taxes or other contributions or penalties'.

68 M.A. and 34 Others Against Finland, supra n. 66, section 'the Law', para. 1 at 11 
so. This was not unreasonable. Furthermore, the Court decided that the measure did not impose an 'excessive burden' on the taxpayers, and so the actions taken by Finland 'did not upset the balance which must be struck between protection of the applicants' rights and the public interest in securing the payment of taxes' ${ }^{69}$

Even if the decision above concerns the application of substantive rules, it illustrates the balanced assessment that needs to be made between the purpose of the measure and the expectations of taxpayers. From this decision, one can conclude that the principle of legitimate expectations does not prevent a retroactive application on a general basis. There may be situations where a retroactive application is justified.

This article submits that the principle of transparency and good tax governance would, in principle, require that TIEAs be predictable and, thus, are not applicable in a retroactive manner. However, as discussed above, a legislature may establish a retroactive application in certain cases, taking into account the taxpayer's rights and the taxpayer's legitimate expectations, such as in cases of abuse.

\section{Policy Recommendations}

Some policy recommendations are provided here regarding how to address a retroactive TIEA application, both at the time of negotiating TIEAs and when regulating this under domestic law.

\section{I A TIEA Should Not Apply Retroactively, Unless the Contracting States Expressly Agree}

Based on the review of the OECD Model TIEA and the tax information exchange provisions included in the OECD and UN Model Conventions, the authors have concluded that these Models do not recommend a retroactive application of their provisions, but that contracting states are entitled to agree on a retroactive application if desired and permitted under domestic law. When no retroactive application is established by the parties, the TIEAs or tax information exchange provisions may, in principle, be interpreted as not having a retroactive application based on the principle of non-retroactivity of Article 28 of the Vienna Convention.

Policy recommendation:

It is recommended that the contracting states adopt clear rules in their TIEAs as regards their temporal application, specifying whether they may have effects on information relevant for taxable periods or charges to tax prior to the date on which the TIEA enters into force.
In the absence of such a rule, contracting states should abstain from applying a TIEA retroactively.

\subsection{The Procedural Nature of a TIEA Should not Justify the Retroactive Application of Its Provision}

As part of this review, some TIEAs have been identified that do not provide clear guidance regarding whether a TIEA may be applied retroactively to previous taxable actions or events. For these TIEAs, one can evaluate whether the procedural nature of a TIEA provision may, in principle, justify its application in relation to 'pending proceedings', which can be defined as an ongoing tax assessment proceeding in relation to a taxable period or charges to tax that arose prior to the date on which the TIEA enters into force.

The review has shown that a TIEA contains not only contain procedural rules, but also substantive rules. Such procedural provisions cannot be applied isolated from the other provisions of the TIEA. Thus, this article submits that this distinction between procedural and substantive rules should not be applied to a TIEA to determine its application to a pending proceeding.

If a developing country would like to take the position that a TIEA should be applied to a pending procedure (i.e. tax assessment procedures existing at the time the TIEA enters into force), this article suggests that such country should include provisions in the TIEA itself regulating this issue, and establish a clear definition of the concept of pending proceeding. In such case, it is recommended to include only tax assessment procedures that have been notified to the taxpayer at the time the TIEA enters into force. This notification requirement aims at protecting taxpayer rights and limiting the scope of the exchange of information obligations assumed by developing countries through a TIEA.

Policy recommendation:

It is recommended to adopt a clear rule in the TIEA regulating whether the TIEA should apply to pending assessment proceedings existing at the time the TIEA enters into force. If so adopted, it is recommended to adopt a restricted definition of the term 'pending proceedings', limiting such retroactive application only to tax assessment procedures that have already been notified to the taxpayer at the time the TIEA enters into force.

In the absence of such a rule, contracting states should abstain from applying the TIEA to pending proceedings.

The review of country practices revealed that Colombia and, potentially, Brazil, allow a retroactive application of TIEAs, provided that the information is still open for review under the domestic rules on the statute of limitations.

\section{Notes}


If countries decide to allow a retroactive application of a TIEA, one alternative would be to follow the approach taken by Brazil and Colombia, stipulating in their domestic law that a retroactive exchange of information is allowed, provided that the information is still open for review under the statute of limitations rules of the requesting state. It is recommended that this position be included both in domestic law and in the TIEA itself or in its memorandum of understanding.

If the taxable period or tax charge has already been subject to a tax audit, the possibility to reopen a case should be limited to situations where, for example, the tax authorities - for reasons that were not under their control - were unable to audit the taxpayer based on the information available at that time, but which have only become available through the TIEA. If second tax audits are generally allowed, there would be in fact no limits to retroactivity.

In accordance with the proposal submitted in the general report delivered at the 69th IFA Congress in 2015, this article submits that domestic law should, in principle, allow only one audit in respect of the same taxable period, i.e. a legal prohibition of repeated audits, subject to certain exceptions. As recognized in that general report:

since audits involves a series of activities for the purpose of ascertaining whether taxpayers have correctly assessed their taxes, the specific implications are: (a) that any step in the procedure cannot be repeated; and (b) that once the audit is completed, it may not start again, even if the tax authorities have committed some fundamental mistakes that affect its validity. Some limited exceptions are admissible in cases of wrongdoing that only becomes known after the audit has been completed, for instance due to information provided by third parties, or amended tax returns by the taxpayers, or some judicial developments related to different matters but sharing a common fact pattern. ${ }^{70}$

Policy recommendations:

It is recommended that countries wishing to provide for retroactive effect in respect of information that is still open for review under the statute of limitations rules, include provisions to reflect this both in domestic law and in the TIEA itself or in its memorandum of understanding.

It is also recommended that countries carefully review and agree whether exchange of information should be restricted for cases that already have been subject to a reassessment proceeding and, thus, are closed, even when the statute of limitations period has not expired. This may also include cases when retroactive application is allowed based on the TIEA.

\subsection{Domestic Law Needs to Determine Whether a Retroactive TIEA Application is Allowed}

Provided that the relevant TIEA does not prohibit a retroactive application, the domestic law of the contracting states will determine whether the TIEA may be applied retroactively. The review carried out by the surveyed countries has revealed that the prohibition of retroactivity included in the Constitutions of Brazil, Colombia, South Africa and Uruguay does not apply directly to TIEAs. However, fundamental rights of taxpayers included in the Constitution or other statutes may set limits on such a retroactive application of TIEAs. In particular, this has been highlighted by the Brazilian and South African units.

From a tax policy perspective, taxpayers' rights such as the right of defence may provide limitations on the retroactive application of TIEAs. It is important to assess taxpayers' rights against the benefits derived from allowing a retroactive application of TIEAs. The question concerns whether it is legitimate to limit taxpayers' rights in the context of a retroactive TIEA application. Such limitation may enable tax authorities of other countries to obtain information needed to enforce their tax laws, which also could benefit other taxpayers (as it may contribute to a more fair tax system).

Policy recommendation:

Legislatures should take a position in domestic law on the issue as to whether taxpayers' rights may be limited as a result of a retroactive TIEA application. Also, legislatures should decide whether domestic law should introduce flexibility by allowing retroactive TIEA application in cases where there is no infringement of taxpayers' rights. This could be done by requiring tax authorities to carry out an assessment of this issue on a case-by-case basis or by having a general rule establishing a general probibition against a retroactive TIEA application, unless the tax authorities can establish that taxpayers' rights are not infringed in the specific case. If the legislature decides to include such type of general rule, it should also consider granting taxpayers the right to oppose such view of the tax authorities.

\subsection{A Legislature May Limit the Obligations of Taxpayers and Tax Authorities in the Case of a Retroactive TIEA Application}

A legislature may decide to allow a retroactive application of TIEA provisions without imposing burdensome obligations on taxpayers and tax authorities.

Policy recommendation:

\section{Notes}

70 Baker \& Pistone, supra n. 55, at 23-24. 
Legislatures that wish to allow a retroactive application of a TIEA without increasing the administrative burden on the side of the tax authorities may establish in the TIEA itself that information relevant for previous taxable periods or charges to tax will be exchanged only if it is already in the possession of the tax administration.

\section{Conclusion}

This article has analysed when a TIEA will be considered to have a retroactive application and when such retroactive application should be accepted based on the OECD and UN Models, as well as law and practices in Brazil, Colombia, South Africa and Uruguay. A TIEA has been considered as retroactive if it requires exchange of information concerning taxable periods or charges to tax prior to the entry into force of the TIEA. The article submits that a retroactive application cannot be justified in general, but it needs to be analysed based on country legislation and practices.

As established in the OECD Model TIEA, the OECD Model Tax Convention and the UN Model Tax Convention, states are free to agree whether a treaty will have retroactive effects. If the contracting states have not agreed on such retroactive application, a treaty should be interpreted as not being retroactive (i.e. as being applicable only to information relevant for taxable periods or charges to tax from the date of entry into force of the treaty).

The review of the OECD and UN Model Tax Conventions has revealed that developing countries similar to the surveyed countries and developed countries address retroactivity in a similar manner and, thus, no specific concerns are applicable to developing countries in relation to this issue.

A review of the TIEAs entered into by Brazil, Colombia, South Africa and Uruguay, reveals that some TIEAs expressly allow for a retroactive application of the exchange of information provisions, covering, for example, previous information without temporal limitations. It has also revealed that other TIEAs do not allow such retroactive application, or simply do not address this issue.

Based on the review of country practice in Brazil, Colombia, South Africa and Uruguay, there is not a uniform approach regarding retroactive TIEA application. Unless the treaty contains specific temporal limitations, Brazil, Colombia and South Africa may generally allow certain cases of retroactive exchange of information. The limitations can be determined based on taxpayer rights or domestic statute of limitations rules (as in Brazil and Colombia).

In Uruguay, the law may not support a retroactive application of a TIEA, but the Uruguayan tax authorities may be in favour of accepting such application, provided that it does not infringe taxpayers' rights.

The principle of transparency and good tax governance would require that a retroactive TIEA application not contravene the legitimate expectations of taxpayers and taxpayers' rights. As recognized by Pistone, '[g]lobal fiscal transparency cannot remain a mere issue of protecting the interest of revenue collection, but must realize this objective in compliance with a proportionate protection of taxpayers' rights'. 71

\section{Notes}

71 Pistone, supra n. 64, at 225. 